\title{
Influence of Globalization on Social Work Educator's Knowledge, Attitude and Practice of Social Work Education
}

\author{
${ }^{1}$ B. Prince Solomon Devadass, ${ }^{2}$ Dr. A. Subramanian, ${ }^{3}$ Dr. Jude Gonsalvez \\ ${ }^{1}$ Assistant Professor, Department of Social Work, Madras Christian College, Chennai, India, 600059, \\ ${ }^{2}$ Associate Professor, Department of Political Science, Madras Christian College, Chennai, India, 600059 \\ ${ }^{3}$ Director, Social Work, Anna Maria College, USA.
}

\begin{abstract}
Globalization is a theme that is at the centre of debate by education policymakers, scholars, professionals and practitioners worldwide. It is a concept that provokes intense debate and examination. Therefore, globalization is described as 'the flow of technology, economy, knowledge, people, values and ideas .... across borders. Globalization affects each country in a different way due to each nation's individual history, traditions, cultures, resources and priorities. A social work-based definition of globalization describes the concept as "a process of global integration in which diverse peoples, economies, cultures and political processes are increasingly subjected to international influences" (Midgley, 1997, p. xi). Additionally, Midgley suggested that globalization indicates "the emergence of an inclusive worldwide culture, a global economy, and above all, a shared awareness of the world as a single place" (1997, p. 21). In the 21st century, globalization leads to changes that challenge social work practice and education, and the idea of postmodernism challenges the validity of a universal knowledge base. This is because where societies are built on different cultural and social assumptions globalizations raises questions about the dominance of any particular set of ideas, both generally and in social work. The influence of globalization on Social Work educator's knowledge, attitude and practice of Social Work education has raised questions about whether Western models of social work education and organization are universal in their application. This research paper will provide a framework for understanding the impact of globalization in social work education in India.
\end{abstract}

Keywords: Influence of Globalization, Social Work Educator, Knowledge, Attitude and Practice, Social Work Education, International Social Work

\section{Introduction}

At the turn of the twentieth century, the attention first began to be fixed up on the necessity for special preparation for persons engaged in charitable activities, individual philanthropists and voluntary agencies provided the impetus and frequently funded the establishments of schools of social work. The earliest schoolsin Amsterdam in 1899, in London in 1903, in New York and in Boston in 1904, in Chicago and in Berlin in 1908 were all established by private initiative. The success of these schools inspired interested citizens- and voluntary agencies and church groups as well- in other countries to launch similar institutions. From 1920 onwards, the movement to establish schools of social work spread all over the world. The first school of social work was started in India by Dr. Clifford Manshardt, the then Director of Sir Dorabji Tata Graduate School of Social Work. During his opening address of the School in 1936 he said “...... this school, which is opening today, represents the first attempt in India to raise social work to the dignity of a learned profession, standing on the same plane as graduate schools of law, medicine or education"i.

After 77 years of establishment of social work education in India, social work education has grown according to the changing trends and needs of the Indian society. Since 1990 the curriculum, teacher- learning aspect, research consultancy and training, infrastructure and learning resources, student support and progression, organisation and management and healthy practices has changed significantly due to the impact of globalisation on Social Work education. However, the objectives of social work education according to the first survey on Social Work education by the United Nations (1950) is to produce social workers who are (i) Intellectually and technically qualified (ii) Personally qualified to perform social work functions in such social welfare programmes as the country concerned has established to promote social and economic well-being. On the whole Social Work education should emerge as a non - partisan, non -sectarian, technical or professional activity, having as its primary purpose the effective implementation of social welfare measures on behalf of members of the community who may be in need of expert assistance in respect of their socio economic problems. So this research is an attempt to understand the pre-globalized era and the impact of globalization era on the Social Work education in India. 


\section{Research Objective}

- To trace the origin and growth of Social Work as a discipline and to analyze the content of Social Work education during pre globalization era.

- To analyze the factors responsible for globalization and globalization's influence on social work education.

- To analyze the influence of globalization on Social Work educator's Knowledge, Attitude and Practice of Social Work education.

\section{Literature Review Origin And Growth Of Social Work Education In The Pre-Globalized Era Introduction}

Social Work as a profession is a product of the $20^{\text {th }}$ century with a strong religious and humanitarian foundation from the past. Historically, Social work is a voluntary effort on behalf of one's neighbor, which sprang from the religious motive which were called 'charity, 'Poor Relief', 'Philanthropy', and 'Social reform'. The giving of alms and the giving of service were the primary efforts to take care of the needy. The giving is more an obligation to the faithful; the emphasis being primarily on the soul of the giver to attain salvation rather than the good done to the recipient. "In some Mohammedan countries at present day reliance on providing for the relief of need by alms of the faithful still continues. The obligation to give personal service - to feed the hungry, to heal the sick - was due perhaps to a more profound religious motive. In both Christianity and Judaism there is a call to comfort the weak hearted, to raise up them that fall, to loose those whom Satan has bound: a call which has contributed most powerfully to our modern desire to rehabilitate the offender and the disabled, to provide kindly care for the old and the ailing and to understand and to help rather than condemn the social misfit" (YOUNGHUSBAND, SOCIAL WORK AND SOCIAL CHANGE, 1964)

At the turn of the twentieth century, the attention first began to be fixed up on the necessity for special preparation for persons engaged in charitable activities, individual philanthropists and voluntary agencies provided the impetus and frequently funded the establishments of schools of social work. The earliest schoolsin Amsterdam in 1899, in London in 1903, in New York and in Boston in 1904, in Chicago and in Berlin in 1908 were all established by private initiative. The success of these schools inspired interested citizens- and voluntary agencies and church groups as well- in other countries to launch similar institutions. From 1920 onwards, the movement to establish schools of social work spread all over the world (Training for Social WorkTHIRD INTERNATIONAL SURVEY., 1958).

To understand the history of Social Work education it would be appropriate to know the history of Social Welfare in two of the advanced democratic countries of the world i.e. United Kingdom(U.K) and United States of America(U.S.A.)The history of Social Work in United Kingdom and Unite States of America may be said to have passed through several phases (Madan, Sixth Edition, 2010)out of which five phases of Social work in U.K and one Phase of Social Work in U.S.A were before the formal Social Work education which began in the year 1898. The phases are discussed briefly for understanding the metamorphosis of Social work profession.

\section{Emergence Of Social Work Education}

In the year 1998 NASW declared $100^{\text {th }}$ anniversary of the social work profession, it is actually the anniversary of the first social work training course in 1898 in the United States. Social Work began as a helping activity under various auspices and not exclusively under the control of religious personnel. There are three patterns in the evolution of Social work education in the world A) Social Work evolving in the United States and Europe as an indigenous response to the conditions of livelihood and the rapid development in the $19^{\text {th }}$ century. B) Social Work was introduced by the Americans and the Europeans to other countries in Asia and Africa as experts to address the problem of "Underdevelopment" C) The introduction, reintroduction of modern Social work in the countries of former Soviet Union and Eastern bloc, including Russia, the nations of Eastern Europe, China and Vietnam under the foreign influence. (M.Healy, 2001 , p. 21)

Professional Social Work education became the cornerstone for the establishment of Social work as a profession. Van Wormer (1997) reports that the first recorded employment of a Social Worker was the hiring of Mary Stewart, a trained Charity Organization Society worker in 1895, by the Royal Free Hospital in London. Her task was to determine whether the patients are eligible for free treatment. Thus the helping profession started to systematize their efforts and to train others to provide similar help. According to de Jongh "Social Work Education emerged almost simultaneously in Britain, the United States, and the European continent at the turn of the century, quickly progressing in each location from lectures to full-time training" (De Jongh, August 8-11,1972) In 1897, Mary Richmond (Richmond.M, 1917) urged for more for an organized training during her speech at National Conference on Social Work. The summer institute started by the Hull house in Chicago became a Summer school in Philanthropic work in the year 1898 founded by New York COS in response to Mary Richmond. Simultaneously in 1899 the first ever School of Social Work began in Amsterdam, the Institute for Social Work Training. It was a two year course aimed at "methodical, theoretical and practical training for 
those who wish to dedicate themselves to certain important tasks in field of Social Work" (Training for Social Work- THIRD INTERNATIONAL SURVEY., 1958) Five field of Social Work were offered: Welfare of the Poor, housing management, "Toynbee Work", Child care for orphans and deserted children, and social work in factories and workshops. Followed by that in 1903, the school of Sociology in London began a 2 year course of theory and practice that grew from the experience of COS. In the mean while the summer school started at New York became a one year full-time course by 1904 and eventually became the Columbia University School of Social Work. In Europe Alice Salomon (M.Healy, 2001 , p. 29) began training course for young Women interested in doing social work and founded the first school of Social work in Germany (Berlin) in 1908 (Weiler.J., Alice Salomon ). Soon Social Work education started growing in many countries. In 1919 and 1923 the National conference of Social Work was held in the United States. The idea of an international conference of social work was suggested by European and Japanese social workers. Dr. Rene' Sand (M.Healy, 2001 , p. 60) of Belgium made an official proposal for the conference. In 1928 the first International Conference of Social Work was held from July $8^{\text {th }}$ to $13^{\text {th }}$ in Paris and it drew 2,481 delegates from 42 countries (Organisation of the International Conference of Social Work, July 8-13,1928).one section of the conference was devoted to Social Work Education. The world meeting in social Work and Social welfare became regular after the first conference in 1928. The second conference was held in Frankfurt (1932) in the midst of World depression and in 1936 in London was focusing on the impact unemployment on the family. The theme of the conference was on "Social Work and Community" The war interrupted the international activities and meetings until 1946. In 1948 the fourth conference was held in Atlantic City, New Jersey. A milestone in organizing social Work conference in India (1952), Brazil (1962) and Kenya (1974) were significant expansion of Social Work beyond Europe and United States. The 1928 conference was also the birth place of three major organizations, International Associations of Schools of Social Work (IASSW), International Federation of Social Workers (IFSW), and International Council for Social Welfare (ICSW).

B) The Spread of Social Work Education beyond Europe and United States

In 1920 International influence played a major role in spread of Social Work education. According to De Jongh "I do not know of any developing country in which social work education was an original product of national development; the origins can always be traced back to strong foreign influences" (De Jongh, August 811,1972, p. 23)

\section{Origin Of Social Work Education In India}

The origin of Social work education can be traced under three main heads: 1) Social Welfare in the ancient and medieval period 2) Social Work during British period 3) Social Work after Independence.

The early history of Social Work education in Latin America, Asia and Africa was introduced by Europeans and Americans. Even though each culture had their rich heritage of service to human beings the international influence had begun to play a major role in the spread of professional Social Work. This pattern was identified by de Jongh(1972). India is another case in which the "birth and early growth of Social Work and its professionalization......was not the product of indigenous inspiration" (L.S.Kudochodkar, 1963) Indian social Work education was heavily influenced by U.S. models for many years.

For eleven years from 1936-47 Tata Institute of Social Sciences was the only school in the country. A second school, the Delhi school (originally located in Lucknow) was started in the year 1946 "under the auspices of the National Y.W.C.A of India, Burma and Ceylon with substantial assistance from the Foreign Division of the Y.W.C.A of the United States" (Yelaja, 1969)This was the first school established as part of the University preparing students for the Master of Arts Degree in Social Work.

Prof. Sanjay Bhatt clearly categorized development of Indian social work education in to into various stages such as:

1. Initiation/ Inception (1936-46), 2. Experimentation (1947-56), 3. Expansion (1957-76), 4. Moderation/Stagnation (1977-86), 5. Explosion (1987) (Thomas, 2010)

It is also observed that most of the Social Work educational institutions are located in urban areas; students practice fieldwork in urban places and prefer jobs in cities and metropolis. However, social work professionals are most needed in rural areas as a huge majority of population lives in rural areas.

The phase after Explosion is an era of Globalization from 1987 where social work education has been influenced by Globalization which gave way to self financing institutes with a changing phase of social work education. This posed a challenge to Social Work education and its objective. The original objective of social work education is Service. Unfortunately Social Work education is commercialized and often neglected the needy and deserving with the influence of globalization.

There are about 350 schools of Social Work in India as per the sources gathered from experts of social work from across the country. Among those Karnataka marked with 72 schools/departments, Maharashtra marked with 60 and several south Indian states occupied large number of social work institutions. Jammu \& Kashmir, Uttarakand, Himachal Pradesh, Assam, Meghalaya, Mizoram, Manipur and Bihar only marked with 
one school/department and there are no schools at all in five of the North-East States.It is also observed that most of the social work educational institutions are located in urban areas; students practice fieldwork in urban places and prefer jobs in cities and metropolis. However, social work professionals are most needed in rural areas where about 70 percent of the population lives.

\section{Globalization and Social Work}

Globalization affects each country in a different way due to each nation's individual history, traditions, cultures, resources and priorities. A social work-based definition of globalization describes the concept as "a process of global integration in which diverse peoples, economies, cultures and political processes are increasingly subjected to international influences" (Midgley, 1997, p. xi). Additionally, Midgley suggested that globalization indicates "the emergence of an inclusive worldwide culture, a global economy, and above all, a shared awareness of the world as a single place" $(1997$, p. 21). In the 21 st century, globalization leads to changes that challenge social work practice and education, and the idea of postmodernism challenges the validity of a universal knowledge base. This is because where societies are built on different cultural and social assumptions globalizations raises questions about the dominance of any particular set of ideas, both generally and in social work. The influence of globalization on Social Work educator's knowledge, attitude and practice of Social Work education has raised questions about whether Western models of social work education and organization are universal in their application.

\section{Participants}

\section{Data Analysis/ Findings}

The research purposefully sought the participation of Social Work educators of Tamil Nadu who have a minimum of one year experience in Social Work education. The participants are members of the department of Social Work/Schools of Social Work faculty who were currently teaching courses in the Social Work degree programs and available at the time of data collection of the study. This focus on Social Work educators is to analyze and investigate globalization as perceived by the individuals responsible for the dissemination of knowledge and for building their attitude for professional practice. The knowledge and attitude and practice on globalization of Social Work educators in addressing the topic of globalization in the classroom could influence preparedness of students in the globalized world.

\section{Key Variables}

In relation to the questions of the research project, the dependent variables for this exploratory study include the definition and dimensions of globalization and the related responses and attitudes of Social Work educators. The independent variables in the study include the data of each of the participating Social Work educators. Other characteristics analyzed as predictive factors for social work educators responses and attitudes toward globalization include the professional and personal backgrounds, resources and international experience.

\section{Definition and Dimensions}

One of the main goals of this research was to provide more clarity about the definition and impact of globalization in relation to Social Work. To understand the phenomena and its meaning a conceptual definition of globalization was asked from the Social Work educators on the study that they could then expand upon, alter, refute or revise in their own terms. The description of the dimension of globalization was collected and categorized to provide examples of the perceptions of Social Work educators.

\section{Responses}

Response to the issue of globalization was captured from the individuals as well as institutional efforts which addressed the topic of globalization in Social work program / Classroom. A response could refer to the inclusion of globalization topics in course subjects or offered as a separate course on the subject.

\section{Knowledge, Attitudes, and Practice}

The variables of knowledge include the definition and impact of globalization in terms of awareness of social work educators on globalization were measured by Yes or No responses. The variables of attitude were measured on an ordinal level as the opinions or beliefs about the importance of this topic for Social Work. The areas of concern on globalization include Social Workers, Social Work Students, Social Work educators and Social Work education. In terms of practice the core globalized areas of Social Work education was measured on an ordinal level substantiated by Global Identity Scale ( GIS-10) to understand the practice areas of globalized Social work educator. 


\section{Results}

\section{The Total Sample}

As mentioned earlier in the methodology, Social work educators from different schools/ department of social work was invited to participate in this study. From a total population of 268 faculty members from 67 Schools of Social Work/departments of Social Work in Tamil Nadu, India, 226 social work educators completed the survey from 54 Schools of Social Work/departments of Social Work in Tamil Nadu with a response rate of $84 \%$. Out of the 226 respondents $76 \%$ filled the questionnaire through hard copy and another $24 \%$ filled the online questionnaire. The data allows for a preliminary inquiry in to the perspectives of Social work educators in the state of Tamil Nadu about globalization and can suggest areas for further research.

\section{Personal Demographics}

To understand the background of the Social Work educators as individuals, the demographics of the sample include age, gender, socioeconomic status (SES), family background, language ability, and travel experience. Table _ shows the social and economic condition will reflect the status of the social work educators in Tamil Nadu. Table 2 shows the mean age of Social Work educators in comparison with the location of college.

Table 1 shows that sixty percent of the participants in the study, who are teaching in the Social Work program in Tamil Nadu were Female. A majority of fifty five percent of the participants Socio Economic Status (SES)belong to the Middle Income Group(MIG) who earn an income of Rs 3 lakhs- 10 lakhs and thirty seven percent of the participants belong to the Lower Income Group(LIG) who earn an income of Rs.1.5 lakhs- 3 lakhst and Economically weaker section (EWS) who earn an income of INR < than 1.5 lakhs.

The study also reveals fifty three percent of the participants belong to the Christian faith and forty four percent of the participants belong to the Hindu religion. A dominant seventy four participants' were married and twenty six percent of the social work teachers are Single. Some of the participants are single because of their Christian religious order. Whereas ninety six participants could only speak English and four percent could speak other foreign languages other than English. The study also shows thirty two percent of the participants have travelled outside India for personal and academic reasons.

\section{Mean Age of the Social Work educators}

Table 2 reveals the location of the college and the type of institution compared with the mean age and standard deviation. A majority of seventy one percent of the participants School/department of Social Work was located in Metropolitan and City. Which proves that the concentration of social work institutions are in the City, pointed out by UGC-Second review Committee report (1975) They recommended Social Work education to be available to other sections of the society. A majority of seventy two percent of the respondents belong to the self financing stream (SFS) which reveals that the social work institutions in Tamil Nadu are dominated by the SFS. The Government aided-autonomous institutions Social Work educators ages ranged from 25 to 55 , with an average $40(\mathrm{SD}=8.25)$. Also the Self Financing Stream - Non autonomous institutions Social Work educators ages ranged from 23 to 58 , with an average of $34(\mathrm{SD}=7.45)$.

\section{Professional Characteristics}

Among the Social Work educators in Tamil Nadu, the sample is composed of individuals with an assortment of professional qualifications and a range of teaching experiences. The faculty represented in this study has different educational systems that present a challenge in comparing the degrees obtained by the social work educators and the levels of courses they are teaching. Their programs were also established at different point of times. Several Government Aided colleges in Tamil Nadu were started before the 1990 and the Self Financing institutions offering social work started after the privatization and globalization in the year 1990.It is very critical to keep these factors in mind in the analysis and interpretation of the data.

Table 3, Specialization of social Work educators in MSW/MPhil/ PhD Specialization

\begin{tabular}{|c|c|c|c|c|c|c|}
\hline \multirow[t]{2}{*}{ 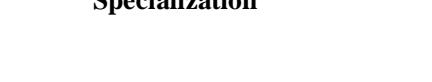 } & \multicolumn{2}{|c|}{ MSW } & \multicolumn{2}{|c|}{ MPhil } & \multicolumn{2}{|c|}{ PhD } \\
\hline & $\mathbf{n}$ & $\%$ & $\mathbf{n}$ & $\%$ & $\mathbf{n}$ & $\%$ \\
\hline Community Development & 82 & 36.3 & 40 & 17.7 & 14 & 6.2 \\
\hline Medical \& Psychiatry & 64 & 28.3 & 38 & 16.8 & 17 & 7.5 \\
\hline PMIR/Human Resource Management & 59 & 26.1 & 39 & 17.3 & 16 & 7.1 \\
\hline Family and Child Welfare & 10 & 4.4 & 4 & 1.8 & 4 & 1.8 \\
\hline Youth Welfare & 3 & 1.3 & 1 & .4 & 2 & .9 \\
\hline Generic/Indigenous & 5 & 2.2 & 9 & 4.0 & 12 & 5.3 \\
\hline Others & 3 & 1.3 & 19 & 8.4 & 20 & 8.8 \\
\hline Not Applicable & & & 76 & 33.6 & 141 & 62.4 \\
\hline Total & 226 & 100.0 & 226 & 100.0 & 226 & 100.0 \\
\hline
\end{tabular}


The table 3 shows the degree of the participants and their specialization. In the MSW course thirty six percent of the participants were specialized in Community Development and twenty eight percent of them were specialized in Medical and Psychiatric Social Work and Twenty six percent of them have dome PMIR/ Human Resource Management. Out of the researched group thirty four percent of the participants have not done M.Phil and sixty two percent of the research participants have not done $\mathrm{PhD}$ respectively. On an average, seventeen percent have specialized in Community development, Medical \&Psychiatry and PMIR/HRM. .Another eight percent has left the specialization and pursuing higher studies and research in other branches.

\section{Area of Interest in Social Work}

The table 4 shows the area of interest in Social Work among the Social Work educators, Thirty eight percent of the participants had interest in Children and twenty five percent of the respondents had interest in working with Youth. Work with children and Youth was the most frequent area of interest among the Social work educators (Wright 2007) although women, elderly, HIV/ AIDS, health or a combination of any of these were also popular area of interest. Five percent of the social work educators were interested in Conflict, Refuges, Disaster management, Migration Communal Harmony, Tribals, Alcohol \& Drugs to name a few. About the Primary methods of Social Work Fifty two percent of the Social work educators preferred Micro practice skill as their first choice and Seventy three percent of the Social Work educators preferred Mezzo practice skill as their second choice. And fifty seven percent of the social work educators prefer Macro practice skill as their third choice.

More than half, fifty one percent of the Social work educators have worked with different cultures which include the different cultures in India and other countries. A majority of sixty one percent of the respondents are not a member of the any association. Thirty percent of the Social work educators are members of the Professional Social Work Association. Only eight percent of the respondents are members of the IFSW and IASSW.

\section{Knowledge}

\section{Impact Of Globalization}

The Social Work educator's knowledge on globalization and their capacity to integrate with Social Work education is shown through the various parameters to understand the impact of globalization.

\section{Definition of Globalization:}

Globalization is a concept with myriad definitions to describe its processes and impact around the world. To gain an understanding of their perspectives on globalization, the social work educators were asked to provide their own definitions of the phenomenon. Descriptions of many of the dimensions of globalization were discussed. These aspects of globalization focused on culture, economics, the environment, politics, society, and technology. This section provides an overview of the general themes in the social work educators' qualitative responses, quotations definitions and descriptions of globalization.

The definitions collected in this study primarily described globalization as a process with many dimensions or indicators. Overall, the range of definitions provided by the social work educators revealed that there are many different perspectives on the phenomenon among the social work educators in Tamil Nadu. Similar to the definitions mentioned above many of the social work educator's defined globalization as "Globalization is the process which enhances the free flow of knowledge, ideas and people across the globe"; "Globalization is the process of international integration arising from the interchange of world views, products, ideas, and other aspects of culture."; and "Process of exchange of goods, services, values and thoughts among countries across the globe and exerting a mutual /reciprocal and dominant influence on the political social, cultural institutions of the country."The concept of globalization as integration, interconnection and global village were often used by the respondents.

Overall majority of the definitions provided by the Social Work educators were very close to the already available literature on globalization. Globalization was frequently defined as a process towards global interdependence and global mindedness. However some of the responses did not reflect the perspective of globalization other than to that it was a) a continuous process, b) it affects every sphere of life c) and it is intensified. The awareness on global yet local and Local yet global imbibes the globalness. As a result, the Social Work educator's definition does not really challenge the existing definition.

\section{Response to Globalization by the Social Work educators}

To develop an understanding of reactions to globalization, the social work educators were asked a) if their institution/school/department of Social Work had a response to this phenomenon, b) whether the topic on 
globalization were included in the curriculum and c) whether students are interested in learning about globalization. The Social Work educators substantiated with examples from the curriculum

The table $5 \& 6$ shows the response to globalization by the social work institutions and educators. Eighty two percent of the Social Work educators agreed that their institution has responded to globalization. Twenty seven percent of the participants respond to globalization by updating the curriculum to the growing needs and skill development for global competence. Twenty five percent participants respond through the skill development for global competence and Sensitizing students on globalization and its impact. Twenty percent of the social work institutions have responded through academic linkages, conferences and international exchanges.

One of the responses to globalization was through curriculum. Seventy six percent of the Social work educators revealed that the Globalization topic was included in their curriculum. Sixty percent of the Social work educators have indicated that atleast one subject includes the globalization topic. And another forty percent indicated that 2-10 subjects include globalization topic in their Social Work curriculum.

The student's response to globalization shows that thirty three percent of the social work educators indicated that most of the students (75\%) are interested in globalization and thirty four percent of the educators indicated that many of the social work students (50\%) are interested in globalization. A majority of sixty eight percent of the Social work educators revealed that 50\% -75\% are interested in globalization topic and out of that forty nine percent belong to the metropolitan and city colleges.

\section{Attitude}

The Social Work educator's Attitude on globalization and their capacity to integrate with Social Work education is shown through the various parameters to understand the impact of globalization.

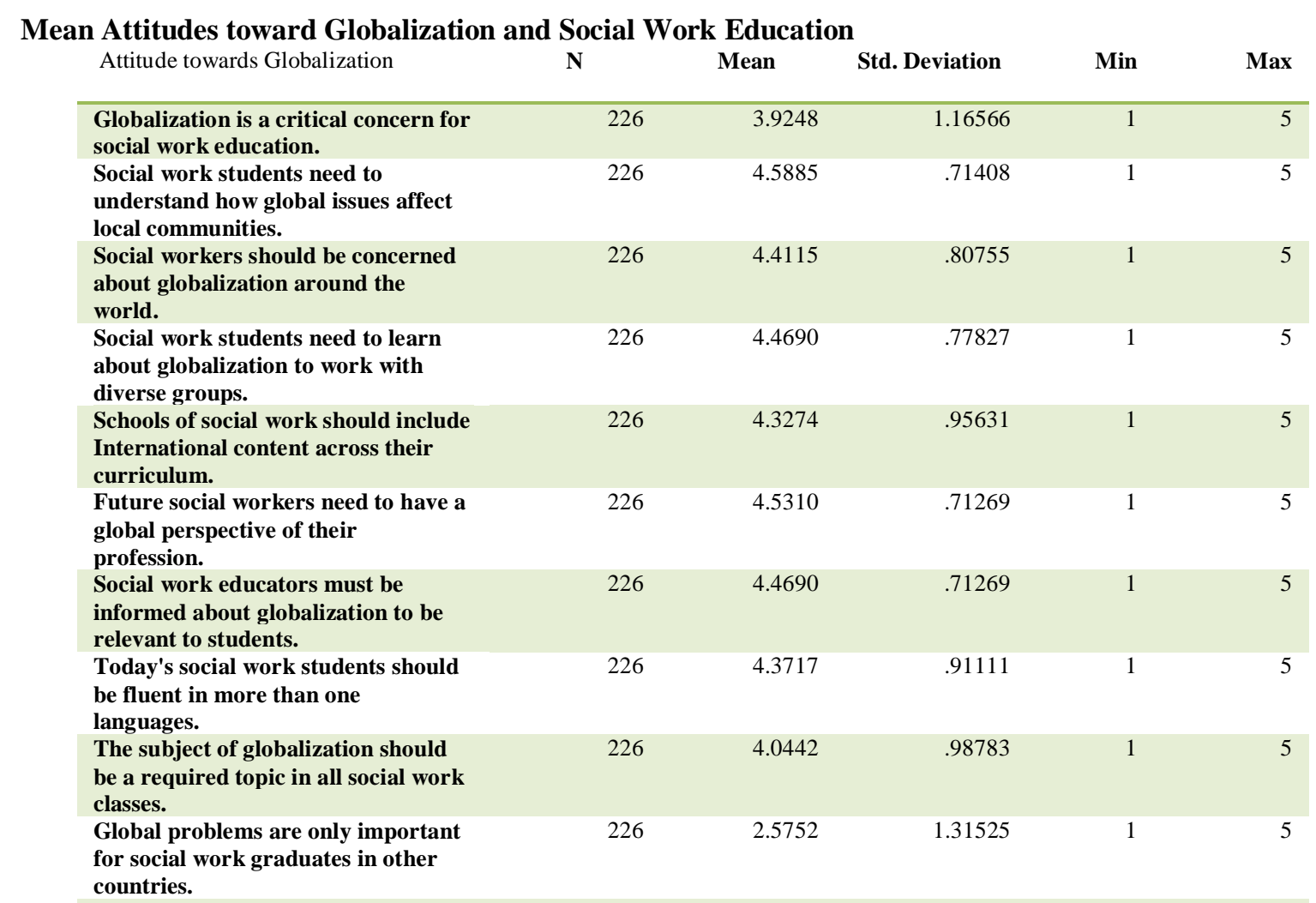

\section{Practice}

The Social Work educator's Practice on globalization and their capacity to integrate with Social Work education is shown through the various parameters to understand the impact of Globalization.

The Social work educators were asked about the impact of the processes of globalization as a) effect on teaching methods, b) challenges to teaching about the subject, c) and the influence on the future of Social Work education and its perceived relevance for the profession 


\section{Globalization' effect on teaching Social Work}

The table 7 shows the globalizations' effect on teaching. Seventy four percent of Social Work educators have access to internet in their department, Seventy eight percent has internet access at home and sixty one percent has internet connection in their mobile phone. Eighty three percent of the social work educators have indicated that globalization has affected their teaching methodology. Out of the eighty three percent forty five percent of them indicated three option, use of LCD projector, use of smart classroom and use of internet in classroom. And a few of them have indicated that globalization has changed their teaching methodology in doing video conferencing and E- content preparation.

A majority of seventy one percent of the participants learnt cross cultural competencies while studying. A majority of seventy one percent of Social Work educators are teaching cross cultural competencies at present...Ninety seven percentage of Social Work educators indicated that globalization has influence on the future of Social Work education. The impact of globalization has forced the trends in Social work in local and global level to remain relevant. This is vivid in the area of interest of Social Work educators.

Influence of Globalization on core areas of Social Work education

\begin{tabular}{|c|c|c|c|c|c|c|c|c|c|c|c|c|}
\hline \multirow[t]{2}{*}{ Core Areas/Levels of Agreement } & \multicolumn{2}{|c|}{$\begin{array}{l}\text { Strongly } \\
\text { Disagree }\end{array}$} & \multicolumn{2}{|c|}{ Disagree } & \multicolumn{2}{|c|}{ Neutral } & \multicolumn{2}{|c|}{ Agree } & \multicolumn{2}{|c|}{$\begin{array}{l}\text { Strongly } \\
\text { Agree }\end{array}$} & \multicolumn{2}{|c|}{ Total } \\
\hline & $\mathbf{n}$ & $\%$ & $\mathbf{n}$ & $\%$ & $\mathbf{n}$ & $\%$ & $\mathbf{n}$ & $\%$ & $\mathbf{n}$ & $\%$ & $\mathbf{n}$ & $\%$ \\
\hline $\begin{array}{l}\text { Globalization impacts } \\
\text { CURRICULAR ASPECTS }\end{array}$ & 5 & 2.2 & 11 & 4.9 & 52 & 23.0 & 105 & 46.5 & 53 & 23.5 & 226 & 100.0 \\
\hline $\begin{array}{l}\text { Globalization impacts } \\
\text { TEACHING-LEARNING AND } \\
\text { EVALUATION }\end{array}$ & 3 & 1.3 & 15 & 6.6 & 31 & 13.7 & 120 & 53.1 & 57 & 25.2 & 226 & 100.0 \\
\hline $\begin{array}{l}\text { Globalization impacts } \\
\text { RESEARCH CONSULTANCY } \\
\text { AND EXTENSION }\end{array}$ & 3 & 1.3 & 6 & 2.7 & 36 & 15.9 & 113 & 50.0 & 68 & 30.1 & 226 & 100.0 \\
\hline $\begin{array}{l}\text { Globalization impacts } \\
\text { INFRASTRUCTURE AND } \\
\text { LEARNING RESOURCES }\end{array}$ & 5 & 2.2 & 9 & 4.0 & 36 & 15.9 & 105 & 46.5 & 71 & 31.4 & 226 & 100.0 \\
\hline $\begin{array}{l}\text { Globalization impacts on } \\
\text { STUDENT SUPPORT AND } \\
\text { PROGRESSION }\end{array}$ & 39 & 17.3 & 12 & 5.3 & 81 & 35.8 & 34 & 15.0 & 60 & 26.5 & 226 & 100.0 \\
\hline $\begin{array}{l}\text { Globalization impacts } \\
\text { ORGANISATION AND } \\
\text { MANAGEMENT }\end{array}$ & 23 & 10.2 & 12 & 5.3 & 33 & 14.6 & 111 & 49.1 & 47 & 20.8 & 226 & 100.0 \\
\hline $\begin{array}{l}\text { Globalization impacts } \\
\text { HEALTHY PRACTICES }\end{array}$ & 23 & 10.2 & 15 & 6.6 & 18 & 8.0 & 99 & 43.8 & 71 & 31.4 & 226 & 100.0 \\
\hline
\end{tabular}

The table _ shows the influence of Globalization on the core areas of Social Work education. The NAAC has identified 7 core areas of social work education for self assessment (NAAC, OCTOBER, 2005) The core areas of social work education is influenced by globalization depending on various factors.

Curricular Aspects: Globalization has impacted the curricular aspects if the social work education. Forty six percent of the Social Work educators have agreed that the curricular aspects are impacted by globalization and another twenty three percent have strongly agreed that the globalization has impacted the curricular aspects.

Table _ shows that globalization has impacted the curricular aspects. Out of the seventy percent of social work educators who have agreed to the influence of globalization on curricular aspects thirty percent of the participants indicated that Curricular aspects of subject framework, Curriculum structure and Process of curriculum development and review has changed due to globalization. Another twenty six percent of the respondents revealed that the process of curriculum development and review was the most impacted among the other aspects in regard to curricular aspects.

Teaching- Learning and Evaluation: Globalization has impacted the teaching-learning and evaluation of the social work education. Fifty three percent of the social work educators agreed that globalization has impacted Teaching -learning and Evaluation. And another twenty five percent have strongly agreed that globalization has impacted the teaching - learning and evaluation.

Table 8 shows that globalization has impacted the teaching -learning and evaluation. A majority of eighty three percent of the Social work educators indicated that the teaching- learning and evaluation was influenced by globalization in evaluation of field work, evaluation of project report, alternate mode of education, revaluation, results and certification and prizes. Four percent of the social work educators have mentioned that Competence of Social Work faculty members have enhanced due to the influence of Social work education. And another ten percent of the social work educators indicated all the responses given are influenced by globalization. 
Research Consultancy and Extension: Globalization has impacted the research consultancy and extension in social work education. Fifty percent of the Social Work educators agreed that the Research, consultancy and extension were influenced by globalization. And another thirty percent of the respondents strongly agreed that research consultancy and extension were influenced by globalization.

Table 8 shows that globalization has impacted the research, consultancy and extension. A majority of seventy nine percent of the Social Work educators indicated that globalization has impacted the research, consultancy and Extension in Consultancy in Social work, welfare and development and Continuing and extension education. Only five percent of the Social Work educators indicated that globalization has impacted the field action projects. This is also due to limited field action projects in the social work institutions.

Infrastructure and Learning Resources: Globalization has impacted the Infrastructure and learning resources in social work education. Forty six percent of the social work educators have agreed that globalization have impacted infrastructure and learning resources. And thirty one percent strongly agreed that globalization has impacted the infrastructure and learning resources.

Table 8 shows that globalization has impacted the infrastructure and learning resources. Thirty eight percent of the Social Work educator indicated that learning resources for the institution, in print, audio visual and electronic forms in library have enhanced because of globalization. Another seventeen percent indicated only office equipment and communication and other facilities are conducive to learn due to the impact of globalization. Forty two percent of the respondent indicated that globalization has impacted the learning resources for the institution and the office equipment and communication.

Student Support and Progression: Globalization has impacted the Student support and progression in social work education. Thirty five percent of the social work educators have a neutral stand in terms of the impact of globalization. Another twenty six percent of the research participants strongly agreed that globalization has impacted student support and progression.

Table 8 shows that globalization has impacted the student support and progression. Sixty two percent of the social work educators indicated that globalization has impacted Student support and progression in Services and activities for students, structured rules for discipline and grievance and Social Work career counseling and alumni network. Seventeen percent of the participants disagreed that globalization has impacted the student support and progression.

Organization and Management: Globalization has impacted the Organization and management in Social Work education. Forty nine percent of the social work educators have agreed that globalization has impacted the Organization and management. And another twenty percent of the participants have strongly agreed to the same.

Table 8 shows that globalization has impacted the Organization and Management. Forty one percent of the social work educators indicated that globalization has impacted the organization and management in regard to setting up of mandatory committee and cells in their institute. And another twenty six percent of the social work educators indicated that globalization has impacted planning, reporting, staff management, mandatory committee/cells in organization and management of social work institutions.

Healthy Practices: Globalization has impacted the Healthy practices in Social Work education. Forty three percent of the Social Work educators agreed that globalization has impacted Healthy practices. Thirty one percent of the social work educators strongly agreed that globalization has an impact on the healthy practices. This indicates a total of seventy five percent of the social work educators agreed that globalization has impacted healthy practices.

Table 8 shows that globalization has impacted the Healthy Practices. Twenty four percent of the Social Work educators indicated that globalization has impacted in all the areas of healthy practices like Regional, national and International collaborations, Contribution to Social Work associations, innovations, and special status from the UGC. Ten percent of the social work educators indicated that globalization has brought about new regional, national and international collaborations.

\section{Conclusion}

The analysis of the impact of globalization on Social Work educator's knowledge, Attitude and Practice was conducted. The various findings provide suggestions for new areas to pursue in future research on the impacts of globalization. The overall results demonstrated that the differences in the type of institutions have an impact on Social Work education, whereas the social work educator's location of the college and personal backgrounds did not necessarily produce divergent responses in their perspectives on the impact of globalization on Social Work education. 


\section{References}

[1]. De Jongh, J. (August 8-11,1972). A retrospective view of Social Work education. In International Association of Schools of Social Work(IASSW), . XVIth International Congress of schools of Social Work, The Hague,Netherlands (pp. (Proceedings)(pp.22-36)). NewYork: New Themes in Social Work Education .

[2]. L.S.Kudochodkar. (1963). Observations. Indian Journal of Social Work, 24(2),96.

[3]. M.Healy, L. (2001 ). International Social Work. New York: Oxford University Press.

[4]. Madan, G. (Sixth Edition, 2010). Indian Social Problems, Vol.2,.

[5]. Organisation of the International Conference of Social Work. (July 8-13,1928). International Conference of Social Work (pp. Vol., pp 5-17). Paris: ICSW.

[6]. Richmond.M, M. (1917). Social Diagnosis. New York: Russell Sage Foundation.

[7]. Thomas, G. (2010). Origin and Development of Social Work. New Delhi: IGNOU.

[8]. (1958). Training for Social Work- THIRD INTERNATIONAL SURVEY. New York: UNITED NATIONS,Department of Economic and Social Affairs.

[9]. Weiler.J., Alice Salomon . (n.d.). Journal of teaching Social Work, 2(2) 165-171.

[10]. Yelaja, S. (1969). Schools of SOcial Work in India: Historical development 1936-1966. The Indian Journal of Social Work, 29(4),361-378

[11]. YOUNGHUSBAND, E. (1964). SOCIAL WORK AND SOCIAL CHANGE. Great Britain: George Allen \& Unwin Ltd.

[12]. YOUNGHUSBAND, E. (1968). EDUCATION FOR SOCIAL WORK - Readings in Social Work Volume IV. Great Britain: George Allen \& Unwin Ltd.

Tables and Figures

Table 1

Frequency and Percentage of Demographic Variables

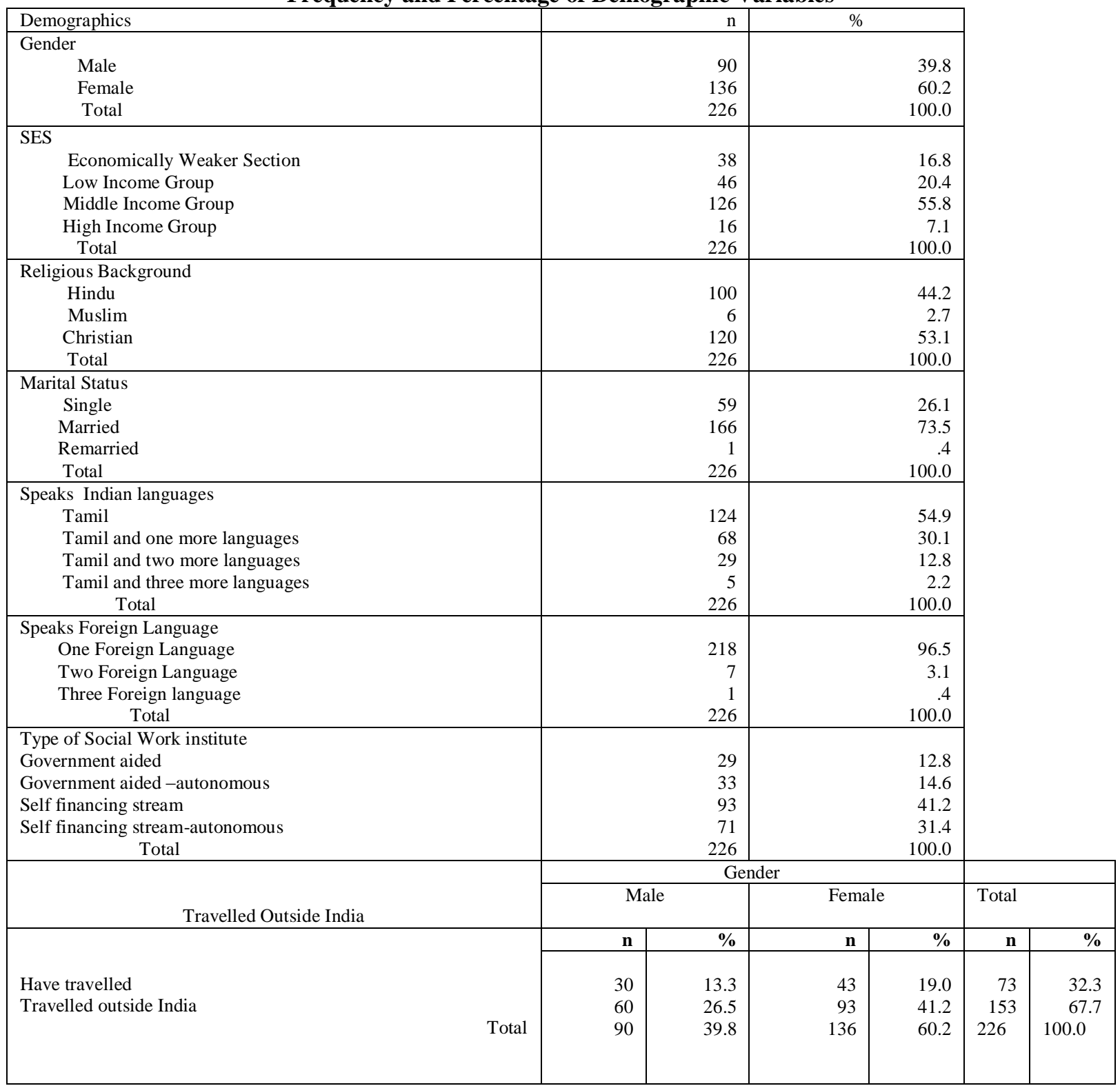


Table 2

Mean Age of Social Work Educators by Location of the College and Type of Institution

\begin{tabular}{|c|c|c|c|c|c|}
\hline Location of College & $\mathrm{n}$ & Mean & SD & Minimum & Maximum \\
\hline Metropolitan & 50 & 37.68 & 7.85 & 25 & 55 \\
\hline City & 110 & 35.90 & 8.54 & 23 & 67 \\
\hline Town & 40 & 31.62 & 6.04 & 24 & 49 \\
\hline \multicolumn{6}{|l|}{ Type of Institution } \\
\hline Government aided & 29 & 35.75 & 8.28 & 26 & 57 \\
\hline $\begin{array}{l}\text { Government aided - } \\
\text { autonomous }\end{array}$ & 33 & 39.87 & 8.25 & 25 & 55 \\
\hline Self financing stream & 93 & 33.91 & 7.45 & 23 & 58 \\
\hline $\begin{array}{l}\text { Self financing stream- } \\
\text { autonomous }\end{array}$ & 71 & 34.56 & 7.77 & 24 & 67 \\
\hline
\end{tabular}

Table 4

Frequency and Percentage of the Area of Interest in Social Work

\begin{tabular}{|c|c|c|c|c|c|c|}
\hline Area of Interest in Social Work & $\mathbf{n}$ & $\%$ & & & & \\
\hline Children & 87 & 38.5 & & & & \\
\hline Youth & 58 & 25.7 & & & & \\
\hline Women & 39 & 17.3 & & & & \\
\hline Elderly & 16 & 7.1 & & & & \\
\hline HIV/ AIDS & 9 & 4.0 & & & & \\
\hline Health & 6 & 2.7 & & & & \\
\hline All the above and others & 11 & 4.8 & & & & \\
\hline Total & 226 & 100.0 & & & & \\
\hline \multirow[t]{2}{*}{ Ranking the Methods of Social Work } & \multicolumn{2}{|c|}{$\begin{array}{c}\text { Rank } \\
\text { one }\end{array}$} & \multicolumn{2}{|c|}{$\begin{array}{l}\text { Rank } \\
\text { two }\end{array}$} & \multicolumn{2}{|l|}{$\begin{array}{l}\text { Rank } \\
\text { three }\end{array}$} \\
\hline & n & $\%$ & $\mathbf{n}$ & $\%$ & n & $\%$ \\
\hline Micro Practice & 118 & 52.2 & 34 & 15.0 & 75 & 33.2 \\
\hline Mezzo Practice & 39 & 17.3 & 166 & 73.5 & 22 & 9.7 \\
\hline Macro Practice & 69 & 30.5 & 26 & 11.5 & 129 & 57.1 \\
\hline Total & 226 & 100.0 & 226 & 100.0 & 226 & 100.0 \\
\hline Work With Different Cultures & $\mathbf{n}$ & $\%$ & & & & \\
\hline Have Worked & 117 & 51.8 & & & & \\
\hline Have not Worked & 109 & 48.2 & & & & \\
\hline Total & 226 & 100.0 & & & & \\
\hline Professional Membership of Individuals & $\mathbf{n}$ & $\%$ & & & & \\
\hline IASSW & 8 & 3.5 & & & & \\
\hline IFSW & 3 & 1.3 & & & & \\
\hline Professional social work association & 68 & 30.1 & & & & \\
\hline Not a Member in any association & 138 & 61.1 & & & & \\
\hline $\begin{array}{l}\text { RAWS/NIPM/NHRD/CHENNAICOUNSELLORS/RCI/ISTR } \\
\text { INTERNATIONAL }\end{array}$ & 6 & 2.7 & & & & \\
\hline Membership in national \& international(123) & 3 & 1.3 & & & & \\
\hline Total & 226 & 100.0 & & & & \\
\hline
\end{tabular}

Table 5

Frequencies and Percentage of Responses to Globalization - Courses/Educators/students interest.

\begin{tabular}{|l|r|r|}
\hline Response to Globalization & n & \multicolumn{2}{|c|}{$\%$} \\
\hline Institution response to Globalization & 186 & 82.3 \\
\hline Responding to Globalization & 40 & 17.7 \\
\hline Do not respond to Globalization & 226 & 100.0 \\
\hline Total & \multicolumn{2}{|c|}{} \\
\hline Globalization Response in Social Work Education & 29 & 12.8 \\
\hline By updating the Curriculum to the growing needs & 30 & 13.3 \\
\hline Sensitizing students about Globalization and its impact & \multicolumn{2}{|c|}{} \\
\hline
\end{tabular}




\begin{tabular}{|c|c|c|}
\hline Skill development for global competence & 16 & 7.1 \\
\hline By Updating the curriculum and Skill Development & 16 & 7.1 \\
\hline Sensitizing students and Skill development & 24 & 10.6 \\
\hline $\begin{array}{l}\text { Non Major Elective/International Exchange/staff and students } \\
\text { linkage/academic-community exchange/ conference }\end{array}$ & 45 & 19.9 \\
\hline Not Responded and others & 66 & 29.2 \\
\hline Total & 226 & 100.0 \\
\hline \multicolumn{3}{|l|}{ Globalization topic included in Social Work Curriculum } \\
\hline Globalization included in curriculum & 173 & 76.5 \\
\hline Globalization not included in curriculum & 53 & 23.5 \\
\hline Total & 226 & 100.0 \\
\hline \multicolumn{3}{|c|}{$\begin{array}{c}\text { Number of Subject taught by the Social Work educator which include } \\
\text { globalization topic }\end{array}$} \\
\hline One Subject & 137 & 60.6 \\
\hline Two Subjects & 65 & 28.8 \\
\hline Three Subjects & 11 & 4.9 \\
\hline Four Subjects & 7 & 3.1 \\
\hline Five Subjects & 2 & .9 \\
\hline Six Subjects & 1 & .4 \\
\hline Seven Subjects & 1 & .4 \\
\hline Ten Subjects & 2 & .9 \\
\hline Total & 226 & 100.0 \\
\hline
\end{tabular}

Table 6

Interest Of Students On Globalization Topic By Location Of College

\begin{tabular}{|c|c|c|c|c|c|}
\hline \multirow[b]{2}{*}{ Interest of Students on Globalization Topic } & \multicolumn{4}{|c|}{ Location of College } & \multirow[b]{2}{*}{ Total } \\
\hline & Metropolitan & City & Town & Village & \\
\hline \multirow[t]{2}{*}{ All the students $(100 \%)$} & 5 & 5 & 6 & 1 & 17 \\
\hline & $2.2 \%$ & $2.2 \%$ & $2.7 \%$ & $.4 \%$ & $7.5 \%$ \\
\hline \multirow[t]{2}{*}{ Most of the students(75\%) } & 17 & 40 & 11 & 8 & 76 \\
\hline & $7.5 \%$ & $17.7 \%$ & $4.9 \%$ & $3.5 \%$ & $33.6 \%$ \\
\hline \multirow[t]{2}{*}{ Many of the students(50\%) } & 19 & 36 & 14 & 8 & 77 \\
\hline & $8.4 \%$ & $15.9 \%$ & $6.2 \%$ & $3.5 \%$ & $34.1 \%$ \\
\hline \multirow[t]{2}{*}{ Not many students(25\%) } & 9 & 26 & 8 & 7 & 50 \\
\hline & $4.0 \%$ & $11.5 \%$ & $3.5 \%$ & $3.1 \%$ & $22.1 \%$ \\
\hline \multirow[t]{2}{*}{ None of the students $(0 \%)$} & 0 & 3 & 1 & 2 & 6 \\
\hline & $.0 \%$ & $1.3 \%$ & $.4 \%$ & $.9 \%$ & $2.7 \%$ \\
\hline \multirow[t]{2}{*}{ Total } & 50 & 110 & 40 & 26 & 226 \\
\hline & $22.1 \%$ & $48.7 \%$ & $17.7 \%$ & $11.5 \%$ & $100.0 \%$ \\
\hline
\end{tabular}


Table 7 Globalization' Effect on Teaching Social Work

\begin{tabular}{|c|c|c|c|c|c|c|}
\hline \multirow{2}{*}{$\begin{array}{l}\text { Globalization Effects } \\
\text { Internet Connection }\end{array}$} & \multicolumn{2}{|c|}{ Department } & \multicolumn{2}{|c|}{ Home } & \multicolumn{2}{|c|}{ Mobile Phone } \\
\hline & n & $\%$ & $\mathbf{n}$ & $\%$ & $\mathbf{n}$ & $\%$ \\
\hline Have Intemet Connection & 168 & 74.3 & 178 & 78.8 & 139 & 61.5 \\
\hline Do not have Intemet connection & 58 & 25.7 & 48 & 21.2 & 87 & 38.5 \\
\hline Total & 226 & 100.0 & 226 & 100.0 & 226 & 100.0 \\
\hline \multicolumn{7}{|l|}{ Globalization effect on teaching Methods } \\
\hline Have effect on Teaching Methods & 189 & 83.6 & & & & \\
\hline Do not Have teachingMethod & 37 & 16.4 & & & & \\
\hline Total & 226 & 100.0 & & & & \\
\hline \multicolumn{7}{|l|}{ Effects on Teaching Method } \\
\hline Use of LCD projector in Classroom & 26 & 11.5 & & & & \\
\hline Use of Smart Classroom & 2 & 9 & & & & \\
\hline Innovative methods of Assignment & 19 & 8.4 & & & & \\
\hline Use of Intemet in Classroom & 4 & 1.8 & & & & \\
\hline All the above & 35 & 15.5 & & & & \\
\hline Three options & 100 & 44.2 & & & & \\
\hline Four Options and above & 1 & .4 & & & & \\
\hline $\begin{array}{l}\text { Video Conferencing/E content preparation/ Guest } \\
\text { Lecture/ ABL Innovationin F.W curiculum }\end{array}$ & 2 & 9 & & & & \\
\hline Not applicable & 37 & 16.4 & & & & \\
\hline Total & 226 & 100.0 & & & & \\
\hline \multicolumn{7}{|l|}{ Learnt Cross Cultural Competencies } \\
\hline Leamt Cross Cultural Competencies & 160 & 70.8 & & & & \\
\hline Have not Leamt Cross Cultural Competencies & 66 & 29.2 & & & & \\
\hline Total & 226 & 100.0 & & & & \\
\hline \multicolumn{7}{|l|}{ Teaching Cross Cultural Competencies } \\
\hline Teach Cross Cultural Competencies & 160 & 70.8 & & & & \\
\hline Do not Cross Cultural Competencies & 66 & 29.2 & & & & \\
\hline Total & 226 & 100.0 & & & & \\
\hline $\begin{array}{l}\text { Globalization'influence on the future of Social } \\
\text { Work }\end{array}$ & $\mathbf{n}$ & $\%$ & & & & \\
\hline Have Influence & 218 & 96.5 & & & & \\
\hline Do not have Influence & 8 & 3.5 & & & & \\
\hline Total & 226 & 100.0 & & & & \\
\hline
\end{tabular}

\begin{tabular}{|c|c|c|}
\hline $\begin{array}{l}\text { Table } 8 \\
\text { Core Areas of Social Work Education }\end{array}$ & & \\
\hline $\begin{array}{l}\text { Curricular Aspects } \\
\end{array}$ & $\mathbf{n}$ & $\%$ \\
\hline Curricular aspects of subject framework & 42 & 18.6 \\
\hline Curriculum Structure & 36 & 15.9 \\
\hline Process of curriculum development and review & 59 & 26.1 \\
\hline $\begin{array}{l}\text { Curricular Aspects/ Curriculum Structure/ Curriculum } \\
\text { development }\end{array}$ & 69 & 30.5 \\
\hline Not specified/others/style of Pedagogy & 15 & 6.6 \\
\hline Not applicable & 5 & 2.2 \\
\hline Total & 226 & 100.0 \\
\hline
\end{tabular}

\begin{tabular}{|l|r|r|}
\hline \multicolumn{1}{|c|}{ Teaching- Learning and Evaluation } & $\mathrm{n}$ & $\%$ \\
\hline Teaching - learning and evaluation of Field work practicum & 32 & 14.2 \\
\hline Teaching - learning and evaluation of Project report & 1 & 4 \\
\hline Use of alternate mode of education & 12 & 5.3 \\
\hline Teaching - Learning for skill workshops & 10 & 4.4 \\
\hline Examination, re-evaluation, Results, Certification and Prizes & 18 & 8.0 \\
\hline Competence of Social Work faculty members & 24 & 4.4 \\
\hline All the above & 116 & 10.6 \\
\hline All the above except Competence of Social Work faculty members & 3 & 51.3 \\
\hline Not Applicable & 226 & 1.3 \\
\hline Total & $\mathrm{n}$ & $\% 0.0$ \\
\hline \multicolumn{1}{|c|}{ Rearch Consultancy and Extension } & 63 & 27.9 \\
\hline Consultancy in Social Work, welfare and development & 54 & 23.9 \\
\hline Continuing and Extension Education & 11 & 4.9 \\
\hline Field Action Projects & 33 & 14.6 \\
\hline All the above & 62 & 27.4 \\
\hline $\begin{array}{l}\text { Consultancy in Social Work, welfare and development/ } \\
\text { Continuing and Extension Education }\end{array}$ & & \\
\hline Not applicable & $\mathrm{n}$ & 3 \\
\hline Total & 226 & 1.3 \\
\hline Infrastructure and Learning Resources & 39 & 100.0 \\
\hline $\begin{array}{l}\text { Office equipment and communication and other facilities } \\
\text { conducive to learning }\end{array}$ & & 17.3 \\
\hline
\end{tabular}




\begin{tabular}{|l|r|r|}
\hline $\begin{array}{l}\text { Learning resources for the institution, in print, audio-visual and } \\
\text { electronic forms in library }\end{array}$ & 86 & 38.1 \\
\hline All the above & 96 & 42.5 \\
\hline N.A & 5 & 2.2 \\
\hline Total & 226 & 100.0 \\
\hline Student Support and Progression & 6 & 2.7 \\
\hline Services and Activities for students & 7 & 3.1 \\
\hline Rules for Discipline and Grievance & 34 & 15.0 \\
\hline Social Work career counseling and alumni Network & 140 & 62.0 \\
\hline Services and Activities for students, Rules for Discipline and & & \\
Grievance, Social Work career counseling and alumni Network & 39 & 17.3 \\
\hline N.A & 226 & 100.0 \\
\hline Total & $n$ & $\%$ \\
\hline Organization and Management & 6 & 2.7 \\
\hline Planning, reporting and review structures and procedures & 12 & 5.3 \\
\hline Staff Management & 32 & 14.2 \\
\hline Financial Management & 94 & 41.6 \\
\hline Mandatory committee/cells e.g. Grievance Cell & 59 & 26.1 \\
\hline ALL THE ABOVE & 23 & 10.2 \\
\hline N.A & 226 & 100.0 \\
\hline Total & $\mathrm{n}$ & $\%$ \\
\hline & 24 & 10.6 \\
\hline Regional, National and International collaborations & 26 & 11.5 \\
\hline Contribution to Social Work Professional associations & 44 & 19.5 \\
\hline Innovations and impact & 54 & 23.9 \\
\hline Special Status e.g. Special schemes from UGC, Centre for & & \\
advanced studies & 55 & 24.3 \\
\hline 1-4 & 23 & 10.2 \\
\hline N.A & 226 & 100.0 \\
\hline Total & & \\
\hline
\end{tabular}

